Urban sprawl and its impacts on land use change in Central Ethiopia Peer-reviewed author version

Dadi, Diriba; AZADI, Hossein; Senbeta, Feyera; Abebe, Ketema; Taheri, Fatemeh \& Stellmacher, Till (2016) Urban sprawl and its impacts on land use change in Central Ethiopia. In: URBAN FORESTRY \& URBAN GREENING, 16, p. 132-141.

DOI: 10.1016/j.ufug.2016.02.005

Handle: http://hdl.handle.net/1942/22723 


\section{Urban sprawl and its impacts on land use change in Central Ethiopia}

This study aimed to understand the major drivers of urban sprawl and its impacts on land use conversion in the peri-urban kebeles of the Dukem town, Central Ethiopia. GIS software was used to create status and location maps of industries out of the GPS data. The results from qualitative data obtained from interviews and focus group discussions showed that more land was used beyond the total size of land allocated initially planned for. Furthermore, urban sprawl has also caused an extensive agricultural land conversion (ALC) that has seriously affected agricultural production. Industrialization, residential expansion and infrastructure development were identified as the leading drivers of ALC that negatively affects the size of cultivated land and food crop production in the hinterlands. In contrast with government policies and community expectations, most converted lands had a very low development status and some of them were underdeveloped and demonstrated leapfrog sprawling.

Keywords: urbanization, sustainable land use, land use management, environmental planning, industrialization

\section{Introduction}

Land is one of the main production inputs, which is a vital element in the socioeconomic development of all nations (Aribigbola 2008; RDPS 2003). Yet, this valuable and scarce resource is in fixed supply (Azadi et al. 2012), requiring sustainable utilization. In developing countries, most people rely on agricultural productions, making land an important asset (Tuyen 2013). Therefore, any change to the agricultural land use in these countries requires thoughtful planning to both conserve the land and reduce the risks of undermining the livelihoods of the people.

Existing literature shows and documents that economic growth and persistent urbanization is an unavoidable global phenomenon that initiates urban encroachment into agricultural lands (Azadi et al. 
2011a; Paul and McKenzie 2012). While some studies state positive outcomes from agricultural land conversions (ALCs) in local communities, others argue against them and report negative consequences (Chen 2009; Nguyen Vu and Philippe 2011; Nguyen and Ho 2013). Therefore, identifying the major drivers of land conversion (LC) and planning to reduce their impacts on the livelihoods of local peoples and their environment are advantageous. This paper focuses on identifying those major ALC drivers and understanding their impacts on the subsistence of local farmers across the peri-urban Dukem town. Besides that, it considers alternatives suggested for appropriate management plans and implementation tools in order to address these drivers.

Industrialization has often been nicknamed as "an engine of economic growth" for nations and usually is an essential and desirable process that accelerates economic growth and reduces long-run poverty (Azadi et al. 2011a; Tariq 2006). Despite serving as "an engine of economic growth", rapid economic growth and a persistent increase in urban population, trigger encroachments and urban sprawling (Cárdenas 1996; Jiang et al. 2012) that undermine agricultural lands and agricultural activities. Numerous studies worldwide have shown industrialization and urbanization as the major drivers of ALCs and have thoroughly documented how it affects the livelihood of local farmers in China, Vietnam, Malaysia, Philippines, India and Spain (Azadi et al. 2011b; Paul and McKenzie 2012). Liua et al. (2009)'s study based on the analysis of land cover maps during 1990-2006 found that most arable lands were lost to urban and rural settlement developments in China's Southern Jiangsu province. A similar study by Tuyen (2013), shows that Vietnam has lost close to half a million hectares of its arable lands to the industrialization and urbanization processes in the sub-urban areas between 1993 and 2008. Likewise, the Netherlands and Germany respectively lost 25 thousand ha from 1996 to 2000 and 42 thousand ha in 2006, whereas the figures are more severe for developing countries such as China and Indonesia where 298 thousand ha of agricultural lands in 2004 and 382 thousand ha between 2000 and 2002 were converted, respectively (Azadi et al. 2011a). Concurrently, development policies set by governments and the subsequent expansion of infrastructures to meet development demands are 
also some other drivers for LCs in the peri-urban corners of countries (Fazal 2000; Xu 2004; Minghong et al. 2004; Wu et al. 2004; Azadi et al. 2011a; Zhong et al. 2011). In this respect, the decision-making processes for land use plan (LUP) quality and land use change are associated with major problems as results from ALCs.

With regard to the effects of ALC, many studies concluded that ALC for non-agricultural uses has brought significant contribution to the overall real growth domestic product (GDP). Nevertheless, controversies exist when it comes to the livelihood of the local people who lose their land. International experiences on the one hand show that, unsustainable and unregulated LC had adverse effects on land tenure security and employment opportunities in agriculture sectors of the peri-urban areas and caused and vunerable grim livelihoods among subsistent farming households (Cardenas 1996; Eila 2000; Chen 2009; Van Suu 2009; Azadi et al. 2011a 2012; Nguyen 2011; Rudi et al. 2012). However, well-studied, well-planned, well-implemented and monitored LCs for industrial development goals would benefit local communities from the many effects of the economy trickling down, such as by providing off-farm and non-farm employment opportunities to access infrastructures (Van Suu 2009; Wu et al. 2011).

In Ethiopia, despite efforts by the government to expand industrial sectors since 2002, the sector has shown little progress and for its contribution to the GDP, its role remained at the bottom of the national economy. By 2011, the sector added less than 13\% to the GDP (MoFED 2013). Conversely, agriculture not only employs more than $85 \%$ of the labor force but also contributes more than $40 \%$ to the national GDP (GTP 2013). Therefore, there is no other way but to protect agricultural lands through appropriate LUP in order to enhance sustainable use, particularly when there is no other sector to replace the significant role of the agricultural sector in the economy of the country.

LUP means the systematic assessment of physical, social and economic factors in such a way as to encourage and assist land users in selecting sustainable options that meet the needs of society (FAO 1996). According to FAO (1996), the LUP's aim is to select and put into practice those land uses that will be best for meeting the requirements of the people while safeguarding resources for the future. 
Generally, the quality of early planning and management tools as well as availability and commitment of government institutions in enforcing legal tools could influence the negative consequences of economic growth and urban sprawling on to the livelihoods of farming households living in the periurban landscapes. In an advanced community, governance plays an important role in enhancing knowledge, interplay, information-sharing, and public training, especially in regard to setting and using policies and regulations for sustainable development. Poor national policy, weak governance and inappropriate institutional arrangements result in low agricultural productivity as well the constraint of the advancement of sustainable utilization (Collier \& Gunning, 1999). According to CLUVA (2013), as far as the planning organization and process is concerned, different levels of decision-making (from national and regional to local level) are linked by the express need for developing strategies as well as the relevant actors. The latter should not only be comprised of national and municipal authorities but also by non-governmental and community-based organizations. Strategies need to link top-down strategic approaches (e.g.) for improving sustainable urban development patterns with site-specific approaches at the local level. In this respect, most urban centers in developing countries, mainly in the sub-Saharan Africa lack practical and effective LUPs and are characterized by the lack of equity and efficiency in land uses (Aribigbola 2008).

Ethiopia is one of the least urbanized countries in Africa with 15 million (17.4\%) out of the projected 86 million people living in 973 towns and cities until July 2013 (Ministry of Works and Urban Development 2013). Nevertheless, with an average of $4 \%$ annual urbanization growth, the country is experiencing rapid urbanization at a rate higher than 3\% average in Africa (Tolossa 2008). As the processes of rapid urbanization led to increased competition over land ownership and higher land prices in urban and sub-urban settings, it is useful to design appropriate LUP in order to balance conflicting interests. In this regard, although the government tried to address land issues by developing LUP of its kind during the deposed regime, success was not achieved due to the failure to translate it into detailed and workable land use plans at local levels [www.ffe.ethiopia.org, 12/9/12]. Under the current 
government structure, watershed based LUP was developed for 12 major rivers so that regions would use it as a base map to prepare LUP of their own. Besides that, the government has made efforts to address rural and urban land administrations by strengthening land administration systems and the development of LUP at national and regional levels. The government put much consideration in to the re-developed land policy and the establishment of the National Urban Development Policy in March 2005 and replaced the Federal Urban Planning Institute with the National Urban Planning Institute in the same year by proclamation No. 450/2005 (Negarit Gazeta 2005).

Oromia Regional State formulated the general watershed based Master Land Use Plan of the region at the scale of 1:50,000 [www.ffe.ethiopia.org, 12/9/12]. From this Master Plan, Oromia Regional State has developed an integrated LUP for Finfine, which surrounds Oromia Special Zone and consisted of 8 towns and 6 rural wereda in 2011. The main objective of this plan was "to save the loss of prime agricultural lands" and assist farmers in the wereda in producing non-cash crops once a year in order to improve their livelihoods as well as develop land use zoning. The efforts were made to remedy accelerated land losses in the peri-urban interfaces of the entire town within the special zone. In this respect, among all other towns in Ethiopia, Dukem town has experienced the highest level of LC for industrialization following its designation as an 'industrial hub' of the country in 2004/2005. In 2012, more than 840 ha of prime agricultural lands were converted for industrial purposes, excluding those lands converted for residential expansions and all other municipal uses. Focusing on this region, this study considers the following key research questions: What are the major drivers of urban sprawl? What are the effects of urban sprawl on land use conversion and food crop production? How can these drivers be addressed through management plans and implementation tools? 


\section{Materials and methods}

\subsection{Description of the study area}

Dukem town is located $37 \mathrm{~km}$ to the south of Addis Ababa within the Oromia National Regional

State (Figure 1), is one of the reform towns of that region and has a city administration municipality and four kebelles, or neighborhood associations, which are the smallest unit of local government in Ethiopia. It is the administrative center of Akaki woreda that is defined by the third-level administrative division of Ethiopia and is composed of a number of kebelles. It is understood that formulating good land governance is the main challenge for the urban development, pressure that is shared between the federal, regional and district governments. According to Proclamation No. 65/2003 article 6 (1), all cities in the Oromia National Regional State are grouped into four levels based on the total size of the inhabitants (ranging from more than 90,000 to 2,000) (Megeleta Oromia 2003). The total population of the Dukem town was around 24,000 by theend of 2011, which falls within the third level.

Based on the data obtained from National Meteorological Satiation, the study area has an average annual temperature and precipitation of $19.5^{\circ} \mathrm{C}$ and $861 \mathrm{~mm}$, respectively (NMS 2013). The area experiences uni-modal rainfall over a three-month period from mid-June to mid-September. Agriculture is the principal source of employment and household income for the majority of the people living in the study area. Subsistence and small scale farming of annual crops is the dominant land-use type together with rearing livestock. Wheat and teff are the dominant annual crops grown and are the preferred food crops for household consumption in the study area (Mengistae 1991). [insert Figure1]

\subsection{Data collection and analysis}

The study employed both qualitative and quantitative data collected from primary and secondary resources. Qualitative data were generated through focus group discussions (FGD) (i.e., composed of seven household heads: (five male and two female)) selected purposively from the rural kebele in 
October 2013. The selections were made based on the households' age (i.e., elderly preferred) and the number of years they lived in the area (i.e., those who lived many years in the area). These data were gathered with the assistance of development agents (DAs) and kebele administration officials. The discussions covered specific topics such as the comparison between the farmlands' size and the income obtained from farming before and after the industrial developments; whether residents were consulted prior to LC and their role in the valuation process of the land and other properties; as well as employment opportunities. Additionally, individual farmland owners were also identified in the study area with the help of DAs and six informants; two from the three kebele were purposively selected for an interview due to the opportunities and challenges that resulted from the industrial and residential expansion across their localities. Further, DAs were also sources of qualitative information in order to complement information obtained from farmers.

Quantitative data on the number and type of licensed industrial investments were collected from secondary sources compiled by investment and land administration offices in the Dukem town. Data on the total lands cultivated and major food crops harvested over five years were also obtained from the agriculture department. In order to supply the quantitative and qualitative data gathered, the Global Positioning System (GPS) was used to collect the coordinates of the spatial location of individual industries, while a digital camera was utilized to take still pictures of industrial and residential expansions over the converted lands. Field verifications for the status of the converted lands and the patterns of residential expansions were applied between February and March 2013.

Three focal people from the department of investment, Land and Environment Protection Unit -the office responsible for the LUP implementation, investment land identification, preparation and status monitoring- were also selected for the interview. The data used in the analysis of the total annual cultivated lands and total production for major crops over the five consecutive years were also acquired from the department of Agriculture's annual reports. Most of the quantitative data used in this study were analyzed using MS-Excel to draw bar graphs and line charts in order to understand the trends of 
the size of cultivated lands in hectare and the total size of food crops including wheat and teff harvested between 2005 and 2010. The ArcGIS tool was also utilized for generating a location map of the study area through drawing the spatial distribution of industries resulted from the GPS coordinates collected in the field. Several other maps were also built using ArcGIS to indicate different layouts of the LUP and to enhance the analysis of land uses in relation to the local environment such as the hydrology and topography of the area.

\section{Results and Discussion}

\subsection{Urban land use}

Owing to the rapid industrialization and urbanization process since 2004, Dukem town has experienced dynamic economic and demographic changes. This dynamism caused urban land expansion that led to the conversion of considerable size of the ALs in the urban fringe. The town did not have LUP until Oromia Urban Planning Institute prepared the first LUP for the town in 2008. Data obtained from the Dukem town Land and Environmental Protection office in 2011 shows that the total urbanized area of the town was 648.7 ha in 2008. The entire urbanized area was classified into different land use types as depicted in the table 1.

[insert Table 1]

Table 1 presents the land size allocated for each land use type in the LUP developed in 2008. The largest segment of the land (nearly $1 / 3^{\text {rd }}$ of the total land) was devoted to housing while industries and storage uses accounted for 148.8 ha $(22.8 \%)$ and 86.2 ha $(13.3 \%)$, respectively. This gives an insight into the leading category of land use from which demands for land originates. A study by Kenneth (2001) shows that early lack of knowledge about the size of the existing urban lands and the quality of urban growth projection is a major challenge that urban centers in developing countries face in order to ensure sustainable and healthy urban growth. Likewise, despite the Oromia Urban Planning Institute's efforts, the implementation of LUP was met with setbacks. However, it was too late for the bureau to 
get full control over the complex land information. Secondly, an investor is given a full mandate to propose the location and the size of the plot of land he/she intends to invest in by a directive No. $128 / 2011$. The role of the investment office of the town is only limited to ensure that the area is not occupied or granted to another project. Thirdly, the investment commission has been welcoming applicants for investment to the town if he/she comes with a project design that shows the type of the project as well as the proposed capital and employment opportunities their project would create. Equally, although article 10 of the contract agreement obliged investors to start developing $25 \%$ of the granted land within six months, they have this right to transfer the land use ownership to a third party by article 9 (2) of the same contract agreement. Therefore, speculative land dealers and rent seekers took the advantage of article 9 (2) to grab the land, but may be unable or not interested any more to develop the land.

Furthermore, the decision on the size and location of investment land could come either from the regional or federal government, especially when the land application comes from foreign investors. Thus, lack of uniformity, broken or delayed information and communication between line offices has created an information gap that was ultimately reflected by the dwindling of urban lands seven years ahead of the proposed life span of LUP. Excessive demand for the land has also initiated the sprawling of investments and settlements on the outskirts into agricultural lands. For instance, the number of individual industries grew from less than 50 before the designation of the Dukem town as Industry Zone in 2005, to over 642 units in 2011 (Investment Office of Dukem town 2012). Considering the worsening land situation in the region, OBLEP prepared a working guideline and standard in 2011. To date, a complete understanding of the existing situation and projecting future trends related to the industrial flow and high in-migration has never been reported.

[insert Figure 2]

As depicted in Figure 2, three years after the approval of the LUP in 2011, the total plots of land granted for industrial and storage utilizations were expanded to twice the total size of land allocated for 
both housing and industry and storage. In other words, the total size of land used for industrial expansion was exceeded by about five-fold (498\%) between 2008 and 2011 compared to the 86 ha (100\%) initially allocated by the LUP in 2008. Likewise, despite 148 ha of land devoted to urban housing on the LUP, 372 ha of urban lands developed for housing in less than three years showing a substantial increase by around two folds (224 ha 151\%) from the primary land size of 148 ha $(100 \%)$. [insert Table 2]

Table 2 shows a comparison of plot sizes approved for some investment projects before and after the guidelines that assisted decision making on the plot sizes to be granted to an applicant according to the predefined criteria, such as investment type and the size of investment capitals formulated in November 2011. In this respect, the process of granting plot size suffers from a lack of uniformity even for similar investment projects before November 2011 (Table 2). There were cases in which an applicant with a small investment capital was granted a larger plot size compared to other projects with a bigger investment capital. For instance, an applicant with an investment capital of USD 494,000 was given 0.18 ha to establish edible oil factory while 0.2 ha was approved for similar projects with a small proposed capital (i.e. USD 64,000) (Table 2). Concomitantly, in spite of the huge investment capital proposed for developing a textile factory (i.e., table 2 , 5a \& b, of USD 1,389,000), only 0.1 ha was approved whereas a similar project with much less investment capital was granted 0.3 ha (i.e., 5 b, USD 167,000). Table 2 also presents the maximum land size required for developments based on the size of proposed investment capital as well as the type (characteristics) of investments. As a result, housing, industrial sprawling and ongoing encroachment into agricultural lands have caused urban lands were inappropriately utilized in three rural kebeles in the peri-urban Dukem, which eventually led to their reintegration into the municipal administration. The aim of the guideline was to ensure uniformity while addressing considerable demands for urban lands, which lead to the sprawling of residential areas and investments into the peri-urban agricultural lands due to uncontrolled and unsustainable land uses. 
In addition to the guidelines, the Oromia Water Works Design and Supervision Enterprise redeveloped the new integrated LUP by revising the old LUP of the town in November 2011. The purpose of the redeveloped LUP was to handle sustained demands of investment lands, housing expansion, regulated agricultural land losses and to remedy land shortages for current and future uses. The redevelopment plan of LUP also aimed to address the probability of the rapid industrialization and urbanization spillovers on local biophysical resources as well as establish and strengthen socioeconomic linkages between urban and rural areas. Figure 3 presents the redeveloped LUP while its detailed explanation is presented in Table 3.

[insert Figure 3]

[insert Table 3]

Similar to the old LUP, more urban lands were earmarked for the expansion of housing, manufacturing industries and storages and the provision of infrastructures compared to the amount of lands allocated to other land use types in the redeveloped LUP (Table 3). These three land use types together sum up 2,508 ha (70\%) of the total 3,586 ha (100\%) of urban boundaries in the new LUP that became the leading drivers of ALC in the three rural kebeles of the Dukem town. Therefore, as shown in Tables 1 and 2, the total size of the urbanized area increased from 648 ha to 3,586 ha in the redeveloped LUP. Also, in both the developed and redeveloped LUP, the largest segment of the urban land was devoted to the housing, industries and storage and the provision of infrastructures.

\subsection{Management and monitoring of urban land use}

As indicated in the preceding section, the OLEPB was established in 2009 with the duties and responsibilities of land administration, preparation and implementing LUPs at the town and city levels. In spite of these efforts, document reviews and discussions with the Dukem town investment office and land administration officials indicated that there is hardly any kind of comprehensive and regular 
management or monitoring practices carried out so far. Hence, up to date data and precise information on the size of converted ALs and the level of such conversions are missing.

\subsubsection{The effects of rapid industrialization and urban sprawling on agricultural lands and food crop cultivation}

Urban LUP preparations based on the scientific principles of planning requires an understanding of complex processes and the active involvement of multi-level stakeholders (Azadi et al., 2011c). According to Samat (2006), three phases are considered crucial prior to any planning in the LUP preparation. These include estimating the urban population growth rates, current and future potential employment opportunities, in-migration and determining urban boundaries. Furthermore, an appropriate implementation of the plan is indispensable to ensure effective and optimal land use (Kenneth et al. 2001).

In this regard, the industrial zone within the Dukem town called "Eastern Industrial Zone", which belongs to Chinese owners, and was granted more than 230 ha of the land used to cultivate food crops in the Xadacha kebele. The size of the land granted solely for this industrial zone is about $260 \%$ times larger than the total size of the 86 ha land allocated on the LUP for this zone.

Furthermore, data obtained from the investment office of the Dukem town shows that more than 515 ha of AL were already distributed for all other investment uses until 2011. On the other hand, the Eastern Industrial Zone and all the other industrial zones proposed creating employment opportunities for up to 46,000 and 15,000 labor forces, respectively (Dukem Investment Office, 2011). This signifies a prospect of continuous pressure on the existing urban lands in the town as incoming people would also demand more housing, along with the expansion of infrastructures in the near or far future (Figure 4. A-B).

[insert Figure 4] 
As argued in many studies (Cardenas 1996; Eila 2000; Chen 2009; Van Suu 2009; Azadi et al. 2011a 2012; Nguyen 2011; Rudi et al. 2012), unsustainable ALC in the urban fringes has been posing negative implications by reducing farmlands and crop yields which threaten the livelihood of local people.

[insert Figure 5]

Figure 5 shows the size and trends of the total cultivated land to grow stable food crops over the six successive harvesting seasons in all the kebeles surrounding the Dukem town. Accordingly, the total size of the cultivated land for wheat and teff growth shows those trends declining. The figure prior to the emerging of industrialization was $365.59 \mathrm{~km}^{2}$ in 2005 while the size dropped sharply to $218.60 \mathrm{~km}^{2}$ six years later in 2011 with a total reduction of $147 \mathrm{~km}^{2}$ (40\%) from the initial size. More specifically, the total cultivated land to grow wheat declined from $230.82 \mathrm{~km}^{2}$ in 2005 to $104.82 \mathrm{~km}^{2}(55 \%)$ in 2011 , whereas the figure for teff shrunk from $134.77 \mathrm{~km}^{2}$ to $93.67 \mathrm{~km}^{2}(30.4 \%)$ over the same period. This clearly shows the swift decline of croplands over time and the growing vulnerability of the rural households for whom agriculture remained the only source of the household livelihood income. Figure 6 shows the declining trends of the total crops harvested over the six successive harvesting seasons considered in this study area.

[insert Figure 6]

In line with the total size of the cultivated lands, the aggregate yield harvested from these lands had shown a successive reduction as well. The overall yield harvested for both crop types decreased drastically between the 2005 and 2011 harvesting seasons. For example, the cumulative yield (teff and wheat) was reduced from 1,280.3 tonnes in 2005 to 867.7 tonnes in 2011. Within the selected harvesting years, the total yield of wheat dropped from 877.12 tonnes in 2005 to 394.3 tonnes in 2011 . Although the figure for teff shows fluctuation from one harvesting season to the next (Figure 6), the overall trend shows a slight increase. An assessment was also made for the price of teff and wheat in the study area that showed a sharp increase in the price of both teff and wheat crops. Interestingly, the 
price of one $100 \mathrm{~kg}$ of teff raised from nearly USD 21.6 in 2005 to just over USD 92 in 2012 while wheat showed a price hike to more than 54 USD in 2012 compared the price in 2005 . In this respect, reduction in the size of household farm size and crop productions combined with the global food price trends have been challenging household food security.

The development practitioners in the study area justify that farmers were in the regular orientation and equipped with land plowing tools and yield enhancing inputs. Apparently, this points to the options of fostering land productivity in order to secure surplus production from the remaining land (Tuyen, 2013). Nevertheless, the main problem for the local people as reflected in the FGD, is that most farmers used to earn their livelihoods from their own fragmented lands and consequently, those who lack the skill or experience to join non-farm businesses may fear that their livelihoods will deteriorate sooner or later. Figure 7 shows the sprawling of industrial expansions across the main highway as well as on either side beyond the plan boundary of the town delineated with pink.

[insert Figure 7]

The redeveloped LUP (Figure 7) indicates the patterns and directions of urban and industrial sprawling. As shown in the figure, numerous industries were established along the highway road connecting Addis Ababa with the Bishoftu town where the lands were used to cultivate crops in the recent years. There are also a couple of industrial plants that expanded the boundaries specified for their development in the LUP into the surrounding arable lands. For instance, the black dotted points/ industries/ inscribed by a light green line are located within the allocated area for the mixed use and residential developments on the LUP. This clearly undermines the credibility of the implementers of the LUP who are supposed to ensure sustainability of land uses in the town. 


\subsection{Status of converted lands}

Investors enter an agreement with an Investment Commission in which they agree to develop 25\% of the land within the first six months and finish the whole project (100\%) over a two years period, from the date the land is given to them [article 10 (1)] in the agreement. According to article 17(20) of the same agreement, an investor who fails to comply with this will be mandated to transfer the land to another potential investor. In spite of this obligation, compiled data obtained from field surveys show that only $28.4 \%$ (Figure 8) of the licensed projects entered operation phases in the Dukem town until the end of 2012. Most of the licensed industrial combined projects (60.8\%) (Figure 8) show that granted investment landowners left the land vacant, fenced and/or froze construction for more than five years. An interview conducted with the heads of investment and land administration offices in Dukem revealed that the agreement is merely symbolic and the government advises local governments not to discourage investors in their respective towns and cities.

Therefore, contrary to the government's ambition to expand the industrialized economy, the rate of development of industrial enterprises is at its lowest level, contributing little in creating jobs as well as in the real Growth Domestic Product (GDP). This is well documented by the Ministry of Finance and Economic Development (MoFED) in its report regarding the actual performance of the Growth and Transformation Plan in 2013. Although the government planned to enhance the contribution of the industrial sector in the real GDP from $10.1 \%$ in $2009 / 10$ to $15.6 \%$ by the end of the Growth and Transformation Plan period in 2014/15, an assessment report for the first two years shows only slight growth $(0.8 \%)$ compared to its performance in $2009 / 10$. However, this amount was much lower than the target plan of $15.6 \%$ (MoFED, 2013). In a question raised to understand the feedback on the current development over the converted land, participants of the focus group discussions (FGD) generally agreed with the government policy of promoting economic growth while complaining seriously over 
the low level of land developments. According to their explanation, some of the warehouses whose construction was already completed has become a safe place to hide during the daytime for some "criminals" and fenced vacant lands has been attracting ducks that are destroying the teff crops of the surrounding farmland. A father of 16 children told the researcher that 'he is very worried about his children's fate, as most of the converted land is left undeveloped and the chance of obtaining employment in the operating industries is slim due to the surplus labor forces'. Figure 8 shows the location map and the status of most of the industrial establishments in two categories (operating and non-operating) data for which was collected in Dukem town. Additionally, the Figure 9 (A-B) shows the current development level of converted lands.

[insert Figure 8]

[insert Figure 9]

Asked if the local communities have been benefiting from the supposed trickle down effects of infrastructure developments in their locality, elders who participated in the FGD, explain different experiences in their kebele. Those from Koticha and Xadacha kebeles have obtained access to power and potable water. However, inhabitants of the Gogecha kebele, which is host to many industries, revealed that they had to use ground water for their daily consumption or travel more than a kilometer to buy water from Dukem town or elsewhere obtaining a twenty litter jerry can of every two/three days from the nearby industries.

\section{Discussion and Conclusion}

The existing LUP of the Dukem town was intended to ensure the sustainable and efficient utilization of existing lands within the urbanized boundary of the town. It was also intended to be a plausible measure for curbing the swift conversion of agricultural lands in urban fringes. The study revealed that significant investments for the industrial and residential expansions remained major drivers of ALCs based on the overall hectares of lands allocated for the LUPs and the size of the lands actually 
distributed. Similarly, studies in European cities such as Munich or Manchester showed that residential areas are concentrated on the largest proportion of ALCs (Pauleit and Duhme 2000, Gill et al. 2007, 2008). Also, the study by CLUVA (2013) in Africa shows that the largest proportionate share of ALCs was found in residential and industrial areas. Other similar studies by Liua et al. (2009), Tuyen (2013) and Azadi et al. (2011a) in China, Vietnam, Netherlands and Germany have also documented industrialization as the major drivers of ALCs. The study showed a delay in the preparation of the binding LUP implementation tools such as guidelines on plot size allocation led to a lack of uniformity in most decisions made on plot size grants for projects. Because of such delays, many hectares of land were distributed much beyond what was allocated on the LUP ahead of time. Moreover, as discussed by CLUVA (2013), this study also concluded that land management and monitoring tools were not only found to be inefficient, but also were not fully implemented. Simultaneously, the rapid industrialization of the town has been accompanied with rapid urban population growth and urban sprawling, leading to the incorporation of the three kebeles in the peri-urban of the town. Such issues significantly affect the size of the total cultivated land and food crop production. Surprisingly, the study revealed that most of the converted lands for industrial establishments were underdeveloped or were not even developed at all. In order to address the major problems resulting from urban sprawling and manage the subsequent ALCs in the peri-urban Dukem, the following comments could be helpful. The government officials at regional and local levels responsible for granting urban lands should stick to the standards formulated by BLEPO. It can also be suggested that higher-level government officials should develop clear and attainable LUP implementation regulations, rules and legal enforcements for the failed or faulty implementations. Furthermore, it is also recommended to develop efficient and workable land management and monitoring systems.

\section{Acknowledgement}

The authors wish to thank Ms. Bethany Gardner from the Department of Linguistics, the State University of New York at Binghamton, for her kind help in improving the English of this text. 


\section{References}

Aribigbola, A. 2008. Improving Urban Land Use Planning and Management in Nigeria: The case of Akure. Theoretical and Empirical Researches in Urban Management, Year 3, No. 9

Azadi, H., P. Ho., and L. Hasfiati. 2011a. "Agricultural land conversion drivers: A comparison between less developed, developing and developed countries. Land Degradation \& Development 22:596-604.

Azadi, H., N. Talsma, P. Ho., and K. Zarafshani. 2011b. "GM Crops in Ethiopia: A Realistic way to increase Agricultural Performance”. Trends in Biotechnology 29(1):6-8.

Azadi, H., P. Ho, E. Hafni, K. Zarafshani., and F. Witlox F. 2011c. "Multi-stakeholder involvement and urban green space performance". Journal of Environmental Planning and Management 54(6), 785-811.

Azadi, H., V. Veronique, V. Acker, K. Zarafshani., and F. Witlox. 2012. "Food Systems: NewRuralism versus New-Urbanism". Journal of the Science of Food and Agriculture 92:22242226.

Cardenas, D. 1996. Effects of Land-Use Conversion on Local Agriculture: The case of Cavite, Philippines. Socioeconomic Research Division, PCARRD, Los Baños, Philippines

Chen, Y., X. Li, Y. Tian,, and M. Tan. 2009. "Structural change of agricultural land use intensity and its regional disparity in China". Journal of Geographical Sciences 19:545-556.

CLUVA (CLimate change and Urban Vulnerability in Africa). 2013. "Assessing vulnerability of urban systems, populations and goods in relation to natural and man-made disasters in Africa". http://www.cluva.eu/deliverables/CLUVA_D2.9.pdf

Collier, P., Gunning, J. W. 1999. "Explaining African economy performance". Journal of Economic Literature. 37:64-111. 
Eila, M.S. 2000. Socioeconomic Impacts of Land Use Conversion: A case study of Raic-Pavia, Iloilo province, the Philippines. UP School of Urban and Regional Planning. http://surp.ph/pages/theses-and-dissertations/.

FAO. 1996. Food and Agriculture Organization of the United Nations Prepared by the Soil Resources. Management and Conservation Service under the guidance of the Interdepartmental Working Group on Land Use Planning, Guidelines for land-use planning: FAO Development Series 1 ISSN 1020-0819.

Fazal, S. 2000. "Urban Expansion and Loss of Agricultural Land - a GIS based study of Saharanpur City". Environment and Urbanization 12(2).

Gill S., Handley J., Ennos R., Pauleit S., 2007. "Adapting cities for climate change: the role of the green infrastructure”. Journal Built Environment 33 (1): Pages115-133.

Gill S., Handley J., Pauleit S., Ennos R., Theuray N., Lindley S., 2008. "Characterising the urban environment of UK cities and towns: a template for landscape planning in a changing climate". Landscape and Urban Planning 87: Pages 210-222.

GTP (Growth and Transformation Plan). 2013. Annual Progress Report for F.Y. 2011/12. Ministry of $\begin{array}{llll}\text { Finance } & \& & \text { Economic Development, } & \text { Ethiopia. }\end{array}$ http://www.undp.org/content/dam/ethiopia/docs/GTP\%20APR\%202004\%20English\%20Versio n_Sept\%207.pdf

Jiang, L., X. Deng., and K Seto. 2012. "Multilevel modeling of urban expansion and cultivated land conversion for urban hotspot counties in China". Landscape and Urban Planning 108:131-139.

Kenneth, G.W. 2001. Sustainability in Urban Planning and Management: In: Kenneth G. Willis, Kerry R. Turner, Ian J. Baleman (Ed.), Urban Planning and Management. Edward Elgar Publishing Ltd, William Pratt House, Northampton, USA. 
Liu, Y.S., J .Wang., and H. Long. 2009. "Analysis of arable land loss and its impact on rural sustainability in Southern Jiangsu Province of China”. Journal of Environmental Management 91(3): Pages 646-653.

Megeleta Oromia. 2003. The Oromia Regional State: The Urban Local Government Proclamation. Proclamation No. 65/2003, Finfine, Ethiopia.

Mengistae, T. 1991. Social Accounts of Three Ethiopian Villages: A study of Institutions and Policy. In: Doss, C. and Olson, C. (Eds.) Issues in African rural development. African Rural Social Science Research Network. Win rock International Institute for Agricultural Development. USA: Arlington.pp.1 -21.

Minghong, T., L. Xiubin, X. Hui., and L. Changhe. 2004. "Urban land expansion and arable land loss in China: A Case study in Tianjin-Hebel region”. Land Use Policy 22:187-196.

MoFED. 2013. Federal Democratic Republic of Ethiopia: Ministry of Finance and Economic Development. Annual Progress Report for F.Y. 2011/12 Growth and Transformation Plan, Addis Ababa, Ethiopia.

Negarit Gazeta. 2005. The Establishment of the Federal Urban Planning Institute, Proclamation. Proclamation No, 456/2005, Addis Ababa, Ethiopia.

Nguyen, V, and T. Ho. 2013. "Effects of Recovery of Agricultural land to life, the Jobs of Farmers in Van Lam District, Hung Yen Province”. Journal of Science and Development 11: 59-67.

Nguyen, V, D. Vu., and L. Philippe. 2011. Peasant response to agricultural land conversion and mechanisms of social differentiation in Hung Yen province, Northern Vietnam. Paper presented at the $7^{\text {th }}$ Asia International conference, Hanoi, Vietnam. http://orbi.ulg.ac.be/handle/2268/100469, 15 Nov. 2013.

NMS. 2013. Federal Democratic Republic of Ethiopia. National Meteorological Station Report, Addis Ababa, Ethiopia. 
Pauleit, S., Duhme, F., 2000. “Assessing the Environmental Performance of Land Cover Types for Urban Planning”. Journal of Landscape and Urban Planning 52 (1): Pages 1-20

RDPS. 2003. Federal Democratic Republic of Ethiopia, Rural Development Policy and Strategy. Addis Ababa, Ethiopia.

Rudi L.M., H. Azadi., and F. Witlox. 2012. "Reconcilability of socioeconomic development, enhancement and environmental improvement in the context of Sub-Saharan Africa”. Global and Planetary Change 86-87:1-10.

Samat, N. 2006. Application of Geographic Information System in Urban Land Use in Malaysia. proceedings of the 4th Taipei International Conference on Digital Earth, University Sains Malaysia, 25-26 May 2006, Taiwan, Malaysia.

Tariq. 2006. Characteristics of industrial effluents and their possible impacts on the quality of underground water. Department of Soil \& Environmental Sciences, NWFP Agricultural University, Pakistan: Peshawar.

Tolossa, D. 2008. Understanding the Realities of Urban poor and their Food Security Situations: A Case study at Berta Gibi and Gemechu Safar in Addis Ababa City, Ethiopia. Institute of Developing Economies, External Trade Organization: V.R.F. Series, Japan

Tuyen, T.Q. 2013. "Livelihood strategies for coping with land loss among households in Vietnam's sub-urban area". Canadian Center for Science and Education 9(15):33-46.

Paul, V., and F.H. McKenzie. 2013. "Peri-urban farmland conservation and development of alternative food networks: Insights from a case-study area in metropolitan Barcelona (Catalonia, Spain)”. Land Use Policy 30:94-105.

Van Suu, N. 2009. Industrialization and Urbanization in Vietnam: How Appropriation of Agricultural Land Use Rights Transformed Farmers: Livelihoods in a Peri-Urban Hanoi Village? Eadn working paper No. 38. Vietnam National University, Hanoi, Vietnam 
$\mathrm{Wu}$, ., M. Fisher, and U. Pascual. 2011. "Urbanization and the viability of local agricultural economies". Land Economics 87, 109-125.

$\mathrm{Xu}$, W. 2004. "The Changing dynamic of land-use change in rural China: a case study of Yuhang, Zhejiang Province”. Environment and Planning A 36:1595-1615.

Zhong, T., X. Huang, X. Zhang, and K. Wang. 2011. “Temporal and spatial variability of agricultural land loss in relation to Policy and accessibility in a low hilly region of Southeast China". Land Use Policy 28:762-769. 
Table 1. Land use types of the Dukem town on the LUP prepared in 2008.

\begin{tabular}{lll}
\hline Land use category & \multicolumn{2}{l}{ Share } \\
\cline { 2 - 3 } & Total area (ha) & Urbanized area (\%) \\
\hline Housing & 148.8 & 22.8 \\
Commerce & 30.3 & 4.67 \\
Administration & 3.6 & 0.55 \\
Services & 21.7 & 3.34 \\
Recreation & 3.7 & 0.57 \\
Transport \& Road Network & 53.9 & 8.3 \\
Industry and Storage & 86.2 & 13.3 \\
Open area & 40.1 & 6.18 \\
Water body & 0.98 & 0.15 \\
Vacant & 260.5 & 40.16 \\
\hline Total & 648.7 & 100 \\
\hline Source: OLEPB & &
\end{tabular}

Source: OLEPB (2011). 
Table 2. Comparison of plots sizes approved before and after setting standard for plot sizes required for projects in 2012.

\begin{tabular}{|c|c|c|c|c|c|c|}
\hline \multirow{2}{*}{ No } & \multicolumn{2}{|c|}{$\begin{array}{l}\text { Approved areas before a } \\
\text { formulated (Nov 2011) }\end{array}$} & \multicolumn{2}{|c|}{ standard was } & \multicolumn{2}{|c|}{$\begin{array}{l}\text { Required area after standard } \\
\text { was formulated (2012) }\end{array}$} \\
\hline & Project Type & $\begin{array}{l}\text { Area } \\
(\mathrm{Ha})\end{array}$ & $\begin{array}{l}\text { Capital } \\
\text { (Thousand } \\
\text { USD) }\end{array}$ & $\begin{array}{l}\text { Price } \\
\left(\mathrm{USD} / \mathrm{m}^{2}\right)\end{array}$ & $\begin{array}{l}\text { Cap. Required } \\
\text { (Thousand } \\
\text { USD) }\end{array}$ & $\begin{array}{l}\text { Area required } \\
(\mathrm{Ha})\end{array}$ \\
\hline \multicolumn{7}{|c|}{ I Agro- processing } \\
\hline 1 & Coffee processing & 1.5 & 50 & 20.9 & 2,193 & 0.24 \\
\hline 2 & Honey processing & 0.3 & 167 & 18.05 & 90 & 0.93 \\
\hline \multicolumn{7}{|c|}{ II Manufacturing industry } \\
\hline $1 \mathrm{a}$ & Electric cable & 4.0 & 33,333 & 74.05 & 518 & 4.5 \\
\hline b & Electric cable & 0.5 & 89 & 74.05 & 518 & 0.12 \\
\hline $2 \mathrm{a}$ & Edible oil factory & 0.18 & 494 & 1,215 & 118 & 0.74 \\
\hline $\mathrm{b}$ & Edible oil factory & 0.2 & 64 & 67.5 & 135 & 0.95 \\
\hline 3 & Leather garment & 2.53 & 1,222 & 67.5 & 1,877 & 1.65 \\
\hline $4 a$ & Soap factory & 3.0 & 128 & 101.78 & 3,053 & 0.13 \\
\hline $\mathrm{b}$ & Soap factory & 0.3 & 167 & 101.78 & 305 & 0.164 \\
\hline $5 a$ & Textile factory & 0.1 & 1,389 & 101.67 & 102 & 1.37 \\
\hline b & Textile factory & 0.2 & 167 & 101.67 & 203 & 0.164 \\
\hline \multirow{2}{*}{\multicolumn{2}{|c|}{ Total }} & 12.5 & 37,270 & 1943.95 & 9,112 & 10.96 \\
\hline & & 1 & & & & \\
\hline
\end{tabular}

Source: Compiled from data, 2012. 
Table 3. The proportion of the land allocated for each land use type in the re-developed LUP, 2011.

\begin{tabular}{|c|c|c|}
\hline \multirow[t]{2}{*}{ Land Use category } & \multicolumn{2}{|c|}{ Proposed Land Use } \\
\hline & Total area a ha) & Urbananizzed area are $(\underline{\%})$ \\
\hline Residence & 1308 & 36.5 \\
\hline Commerce & 215 & 6.0 \\
\hline Services & 63 & 1.75 \\
\hline Administration & 11 & 0.3 \\
\hline Industry and Storage & 658 & 18.34 \\
\hline Recreation & 100 & 2.78 \\
\hline Reserved & 201 & 5.6 \\
\hline Forest \& Buffer & 428 & 12.0 \\
\hline Urban agriculture & 60 & 1.7 \\
\hline Transport \& Road Network & 542 & 15.1 \\
\hline Total & 3586 & 100 \\
\hline
\end{tabular}

Source: Generated from OLEPB documents, 2011. 
Figure 1. Location of Dukem town, 2013.

Figure 2. Major land use types in the LUP and implementation history.

Figure 3. The redeveloped LUP of Dukem, 2008 (Source: Oromia Water Works Design and Supervision Enterprise, 2013).

Figure 4. Residential and Industrial sprawling into agricultural land, Dukem: (A) Residential sprawling. into agricultural land, (B) Industrial sprawling into agricultural land (Photography by the first author, 2013).

Figure 5. Size of the total cultivated land to grow cereals in Akaki district, 2005-2011.

Figure 6. Total food crops harvested over five harvesting seasons, 2005 to 2011.

Figure 7. Patterns of Industrial sprawling in the re-developed LUP of Dukem town, 2012.

Figure 8. The current development level of industries established over converted lands in Gelan and Dukem towns.

Figure 9. Fenced vacant and warehouses whose construction freeze for more than 6 years: (A) View of vacant and frozen over converted ALs, 2013. (B) View of fenced and protected construction over converted ALs, 2013 (Photography by the first author, 2013). 